\title{
Relationship Between Learning Environments, Principal's Gender and Students' Academic Achievement in Public Secondary Schools in Marakwet East Sub County, Kenya
}

\author{
Charles K. Kisigot $^{1 *}$, Prof. Paul A. Ogula ${ }^{2}$, Dr. Jennifer Munyua ${ }^{3}$ \\ ${ }^{l}$ Department of Post Graduate. The Catholic University of Eastern Africa \\ ${ }^{2}$ Faculty of Education, Department of Post Graduate Studies. The Catholic University of Eastern Africa \\ ${ }^{3}$ Department of Educational Psychology. The Catholic University of Eastern Africa
}

*Corresponding Author: Charles K. Kisigot, Department of Post Graduate. The Catholic University of Eastern Africa, Kenya

\begin{abstract}
This study was developed to investigate the relationship between learning environment, Principal's gender and students' academic achievement in public secondary schools in Marakwet East Sub County, Kenya. The study specifically sought to provide responses to the research questions below; what learning environment exists in public secondary schools in Marakwet East Sub County? What is the level of academic achievement of public secondary schools in Marakwet East Sub County? Is there a relationship between Principal's gender and secondary students' academic achievements? Is there a relationship between learning environment, Principal gender and students' academic achievement? This study was anchored on Sociocultural Learning Theory of cognitive Development that was put forward by a psychologist Lev Vygotsky (1978) but published by Harvard University Press. This theory postulates that parents, caregivers, peers and the culture at large were responsible for developing higher order functions in human beings. In line with this believe, the theory suggested that human learning require to be a social matter that is required to take place in processes. Jean Piaget and his supporter, Boyle (1994) also postulates that learning is an active process and learners are constructors of their own objective reality, understanding and knowledge of different things through experiencing things and reflecting on those experiences. The study adopted mixed methods research that combined elements of quantitative and qualitative designs. Causal comparative for quantitative and phenomenological for qualitative research designs were employed. The study focused on 10 public secondary schools, 10 Directors of Studies and 140 teachers within Marakwet East Sub County. The study used stratified and simple random sampling to select a sample of 103 secondary school teachers. Descriptive and inferential statistics were used to analyze data. Data were collected through administering questionnaires to teachers, interviewing Principals and Directors of Studies, carrying out naturalistic observation, check listing of physical learning environment and academic document analysis. Collected quantitative data was analyzed using ANOVA, and $t$-test. Qualitative data were analyzed through thematic and in-depth descriptions of observed and recorded data. Frequency tables and graphs were used to present the analyzed quantitative data while qualitative data will use in-depth explanations, description, and discussions. This study found the need to implore education stakeholders to strive to manage the secondary schools learning environment and embrace gender equity for enhanced academic achievements.
\end{abstract}

Keywords: Learning Environment, Principal's Gender, Students' Academic Achievement

\section{INTRODUCTION}

In the opinions of Cohen (2015) learning environment is the quality and character of school life. It is based on patterns of school life experiences and reflects norms, goals, values, interpersonal relationships, teaching, learning and leadership practices, and organizational structures. Tshui and Cai (2016), on the other hand, described learning environment as an orderly environment in which the school family feels valued and able to pursue the schools mission free from concern about disruptions and safety. Rohana, (2017) who describes secondary school as a formal organization where teachers and students' activities are planned, organized and controlled both internally and externally concludes that this is an epitome of the learning environment.

Studies that have been conducted on the global scene to determine the factors that influence students' academic achievement have focused on performance verses either school factors, motivational level, 
administrative styles, class sizes and enrollment, gender difference, location, infrastructure, or/and school cultures. In Kuwait, for instance, Al-Enezi (2002) studied the relationship between school building conditions and academic achievement of $12^{\text {th }}$ grade students in Kuwaiti public schools, and he said that school environments needs to be suitable ones. He proposed that school environment should be positive and suitable to satisfy students' life as well as promote democratic society. This can happen if school climate is one that value students, gives room to self-expression, and provides emotional security through guidance and counseling services and providing physical safety.

Ruszala (2008) investigated the condition of high school facilities in the Commonwealth and their relationship to teacher satisfaction, found that learning environment, such as the school location and gender plays prominent roles in language teaching and learning. This view has been emphasized elsewhere in some quarters to have effects on students' academic achievement. Regionally, Bogonko (1992) has observed that conditions differ significantly in Africa. He wrote that indigenous education has long been environment centered, localized and omnipresent, as opposed to the Western model with its strengths in literacy, numeracy and formalism.

According to Obanya (2003), education does not occur in a vacuum. It grows in a socio-politicaleconomic environment and there can be no education without a society. Thus, a society provides a macro environment in which a school is located and from which it draws its resources. Within the school, there are also macro environment which influences the operation and the extent to which educational objectives can be achieved. Therefore, the development of an individual, through knowledge and skills acquisition in school, could be influenced positively or negatively by the sociopolitical and economic conditions of the environment. Akubue (2016) has argued that a noble learning environment has the advantage of fostering desirable behaviour and attitude. School environment reflects the physical and psychological aspect of the school that are more susceptible to change and provide the pre-conditions necessary for teaching and learning to take place.

Namusisi, (2015) in a research done in Uganda, showed that well-designed classrooms can increase learning progress in reading, writing and Math by $16 \%$. Better service delivery and enhanced student performance is as a result of learning environment and embraced gender equity. How students relate with each other, or with their teachers and the learning environment have effects on academic achievement to be realized at end of educational circle. This supports the call for provision of safe, health, and stimulating environment with enough learning facilities. Raturi and Kedrayate (2015) concur with this view and have reported that learning environment is an arena that exerted influence on performance of learners especially when co-curricular activities, teaching techniques and appropriate relationships were provided, developed, maintained and well-coordinated. This shows that student relationships and interactions with school environment are important and beneficial.

Carothers and Reis (2013) defined gender as the range of physical, biological, mental and behavioural characteristics pertaining to and differentiating between masculinity and feminity. Gender is one of the personal variables with relationships to differences in motivational functioning and in selfregulated learning patterns in boys and girls. In the traditional times, there were some work reserved for boys and girls. This believes have been extended to educational setting. There are also vocations regarded as men's and women's.

Kashu, (2014) has argued that gender related disparities have also characterized Kenyan education system at the national level, at regional level and at all levels of education from primary to university in favour of males.

According to Yusuf (2004) and Adeyemi (2008), poor academic performance of students in public secondary schools in national examination had made parents lose confidence on the ability of their children to produce good results. Experience had shown that there was a high rate of indiscipline in secondary schools. It has also been observed that lateness to school, absence from school, noisemaking, quarrelling, rudeness to school authority, deliberate physical harm to others, forgery, cheating in examination and a host of others, were daily happenings in Secondary Schools. All these tend to make the schools ineffective. Evidence of students' moral paucity is more conspicuously seen as high crime in the society and that of the institutions of learning. Adeyemi (2008) further posited that the root cause of these moral laxities translating in higher crime waves is traceable to the nonteaching of ethics, when the students are at the primary schools. This imply schools with adequate 
learning environment contributes a lot to mopping up of expected learning outcomes which eventually will facilitate better academic achievements.

This calls for concerted efforts by stakeholders to encourage effective teaching and learning in secondary schools since they have relationships. Similarly, trends reviewed above worry intellectuals especially on the roles of males and females in social, political, scientific and technological development of a country, thus the need to do a study on them for information and informed decision making.

Institutional factors in relation to effects of learning environment and gender on academic achievement include the environment of teachers, requisite facilities, and learning space. In extreme circumstances some school spaces have been used as battle fields, faced insecurity and absence of teachers (Kirui, 2016). Recently security apparatus in the north rift reported that some Marakwet youths crossed over, raided and drove hundreds of Pokot cattle. Two youths died in the milieu and several others were seriously injured (The Sunday Standard, 7th 2018). This contravenes the growth and rapidly increasing demand for better education and life-long learning in Kenya and especially in the region. Content delivery approaches have meant that educational institutions should be equipping variety of facilities. Recurring conflicts such as cattle rustling especially in the Arid and Semi-Arid areas have often disrupted learning and adversely affected school systems. It has been observed that boys in arid and semi-arid areas keep moving with poisoned arrows in defense of their cattle even on school hours. Security agencies report explains that cattle rustling menace have led to many deaths in some parts of Turkana, Samburu, Baringo and Marakwet. Those boys who survive suffer poverty, neglect and live psychological trauma.

The Sessional Paper No. 1 of 2005 and the policy of integrating secondary education as part of basic education had targeted transition rate of 70 percent from primary to secondary schools by 2008 ,with doubling in 2010 and tripling by 2015(MOEST, 2005). It is based on the background above, and in line with the EFA goals, that the Kenya government has heavily financed improvements in schools' environment (Daily Nation, $27^{\text {th }}$ June 2017 p.15). Therefore, in 2013/2014 financial year, the National Treasury allocated 24 billion to 68secondary schools; 108 billion was disbursed to 88 secondary schools and another 300 million to 238 secondary schools through infrastructural development in the 2014/2015 financial year. This was to keep pace with the increased enrollments at secondary school level due to the introduction of Free Primary Education (FPE) initiative in 2003 and Kenya Government's policy of increasing transition rates from primary to secondary schools. As a legitimate government whose responsibility is promoting education in Kenya, the government required to increase funding at this level and provide funds for school programmes improvement.

Students' academic achievement is a pointer of the effectiveness of schools as well as a major determinant of the well-being of youths and a nation (Yusuf \& Adigun, 2010). The learning environment and gender practices within this sub county and the geographical landscape within the low lands and the highlands vary and may be other areas of concern in this study. Secondary students' academic achievement in the Sub County on average has been low for quite some time. In the 2017 KCSE national examinations, for example, all the 18 secondary schools, graduated only 38 candidates who met the minimum university entry points of a $\mathrm{C}+$ (plus or 7points). The sub county's mean score for that year 2017 was 3.395, a grade equivalent to 3 points.

Previously in 2016, only 29 candidates from all the secondary schools managed to score grades above $\mathrm{C}+$ (plus) and qualified to the university according to Kenyan standards. One girls-only school produced 19 out of the total 29who joined universities that year (MOEST Report, 2018). The year 2016 mean was 3.333 a D plain (equivalent to 3 points). The 2015 KCSE results were satisfactory. The year's realized a mean was a 'C' plain (an equivalent of 6 points), in 2014 the mean was a 'C'minus (an equivalent of 4points). Many of these schools registered poorer results with some missing results in 2014 and in 2013 whose mean was 4.458(equal to D+, plus). This can be attributed to a number of factors such as school learning environment, the teachers, teaching learning resources, social environment and the students' gender. Absenteeism, low entry behaviours, school dropout, engagement in outlawed cattle rustling and perhaps early marriages is observed and reported by the education officials in the study area.

These factors might in one way or the other have contributed to the students' learning outcomes especially in Kenya Certificate of Secondary Education (KCSE) national examinations. Education 
stakeholders in the study area have made efforts to provide requisite materials and equipment to the secondary schools, paid fees and other school levies, mobilized resources and even built more secondary schools. The students attend school each other school term and sit for the internal (formative) and national (summative) evaluation or examinations. The secondary schools have continued to post poor examination results in the past ten years. The KCSE mean of the sub county was 3.395 in 2017, 3.333 in 2016, 5.796 in 2015, 5.53 in 2014, 4.458 in 2013, 4.712 in 2012, 4.722 in 2011, and 4.18 in 2010 (MOE Report, 2018). If this situation is left an unchecked and continuous for long it could lead to fewer graduates, hence socioeconomic underdevelopment of the study area.

\section{Statement Of The Problem}

Unlike in all secondary schools in Marakwet east combined, where only 38 out of 654 candidates who sat for $2017 \mathrm{KCSE}$ exams that met the minimum university required entry points, and attaining a mean of grade $\mathrm{C}+$ equivalent to 7 points out of 12 maximum points or an 'A' plain, other individual secondary schools or sub counties were graduating over hundred to tertiary institutions and university. Either, in 2016, out of 546, only 29 candidates scored C+ (plus) and above. It was one girls-only school that produced 19 of the 29 qualified candidates in the 2016 KCSE national examinations (SCDE, 2017). The mean grade for this year was a C-(an equal of 5 points). The 2015, 2014, and 2013 KCSE mean grades stood at D+ (an equivalent of 4 points) with majority of the schools registering poorer results that were characterized by missing marks or withheld results.

This can be attributed to a number of factors such as school, teachers, students' gender and surrounding environments. Cultural practices, like engaging in cattle rustling and perhaps early marriages, student/teacher absenteeism, and school dropout could be observable practices in the study area and might in one way or the other have contributed to the students' learning outcomes in KCSE. The secondary schools have continued to post poor examination results in the past ten years despite the above efforts. This show learning environment differences and disparities in sexes is an area of interest to be studied to seek answers to existence of poor students' academic achievements. The results and achievements of secondary schools in this sub county (MOEST, 2016) indicates existence of declining trend in academic achievement compared with other secondary schools in entire Elgeyo Marakwet County. KCSE means of 4.35, 4.012, 3.87, 3.67 and 3.225 from 2015 to 2019 in such a long period is really challenging (MOEST, 2019). If this situation is left an unchecked and continuous for long it could lead to fewer graduates, lower skilled and knowledgeable human resources hence leading to socioeconomic underdevelopment of the study area.

Several studies have been conducted on students' academic achievement. Kiptum (2018) focused on the Influence of school physical environment on teachers' satisfaction in selected public primary schools in Elgeyo Marakwet County. Lulley (2018) examined the social conflicts affecting teaching and learning in public primary schools of Elgeyo Marakwet County. While Chebii (2014) examined factors influencing performance of pupils in KCPE in Kapsowar Divison. Though these studies have shown relationship between school physical environment and teachers satisfaction, (Kiptum, 2018); social conflict and teaching and learning (Lulley, 2018); and factors influencing KCPE performance, none of them has been carried out on effects of learning environment and gender on academic achievement in public secondary schools in Marakwet East Sub County. Therefore, this study sought to find out the effects and relationships of learning environment and gender difference on secondary school students' academic achievements in Marakwet East Sub County, Kenya so that answers to existing gaps are developed.

\subsection{Research Questions}

The following research questions will guide the study:

- Is there a relationship between learning environment and students' academic achievement?

- Is there a relationship between Principal's gender and secondary students' academic achievements?

- Is there a relationship between learning environment, Principal gender and students' academic achievement?

\subsection{Research Hypotheses}

$\mathrm{H}_{1} \quad$ There is a statistically significant difference between mean learning environment scores and students' academic achievements. 
Relationship Between Learning Environments, Principal's Gender and Students' Academic Achievement in Public Secondary Schools in Marakwet East Sub County, Kenya

$\mathrm{H}_{2} \quad$ There is a statistically significant difference between Principal's gender and academic achievements.

$\mathrm{H}_{3} \quad$ There are relationships between learning environment, Principal's, gender and academic achievements.

\subsection{Theoretical Framework}

This study was based on socio cultural learning theory and constructivist theory. The theory of sociocultural learning theory was put forward by Lev Vygotsky (1978), whereas constructivist theory was put forward by Boyle (1994). The sociocultural theory stated that all human learning was a social affair that involved interactions with other people such as parents and significant others; that all children were born with basic biological constraints in their minds. The Vygotsky (1978) theory also noted that cognitive development in a learner differ from culture to another. This implied that cultures provided tools of intellectual adaptations and that play in learning was important. This means teachers require understanding individual learners, cultures or environment and parents for desired outcomes to be realized. The learning environment therefore matters as far as Vygotsky's theory of sociocultural learning was concerned. Similarly, the constructivist worldview posits that learning is an active process. The student is an information constructor who actively constructs or creates their own subjective representations of objective reality and thought. This theory views learning as the active process of drawing meaning from experience (Semple, 2000). The responsibility of knowledge transfer lays with the learner, not the teacher. The learning environment designs based on this theory are student-centered, collaborative, cooperative, and experiential. Teachers serve as facilitators (Caine and Caine, 1991). Learning environments should be safe, challenging, comfortable, social, and should enhance interaction. Learning opportunities need not take place in the classroom setting alone. They may also take place in hallways, outdoors, or during lunchtime (ibid). Moore (2014) explained the interactional constructivist theory that conceptualizes the learning environment into indoor, outdoor and neighbouring environments. Since this part of the country is Arid and Semi-Arid, marginalized and with rampant insecurity, the theory provides information to stakeholders to safeguard the interests of the learner by providing adequate security, human and physical resources that would make the learning environment appropriate and conducive for habitation as well as for learning. This theory is applicable to this study since all learners require social interaction to perform well. Similarly learners require positive thinking people to work with. These people include teachers and parents. Also, the theory equips teachers with knowledge to understand student/learner development and provide accordingly. There is one demerit associated with this theory, it lacks structures, yet some students may need structured environment.

\subsection{Effects of School Learning Environment on Students' Academic Achievement}

Outside the USA there is evidence of a new interest in the influence of school facilities on student achievement. For instance, Al-Enezi (2002) studied the relationship between school building conditions and academic achievement of $12^{\text {th }}$ grade students in Kuwaiti public schools. Ruszala (2008) investigated the condition of high school facilities in the Commonwealth and their relationship to teacher satisfaction. Stress-free environments were assumed to positively affect the learning process. Evidence in the mid 1980's confirmed the idea of a relationship between school condition and academic achievement (Conners, 2012).

In Brazil, DiGropello (2014) conducted a study on the effect of physical environment in public schools on students' achievement. The study employed experimental research design and targeted a total of 30 secondary schools in urban and rural settings. The researcher compared the physical environment of urban and rural secondary schools. The study revealed that schools in Brazil had inadequate funding, poorly trained teachers, rigid pedagogies and over regulated management. The poor funding had contributed to poor development of physical infrastructures. The study also revealed that majority of the secondary schools in the rural settings were poor furnished to cater for students educational needs and compared to schools in the urban setting.

The poor physical infrastructures were evident in the poorly light and poorly ventilated classrooms with cracked walls and floors which had made concentration in classes very low among the students and educators. The poor physical environment had demotivated teachers which had contributed to low academic achievement. All these made teachers work under a pressing environment leading to poor students' academic performance. 
In Tanzania Limo, Too and Kipng'etich (2017) investigated the Perception of teachers on availability of instructional materials and physical facilities in secondary schools of Arusha District, Tanzania. This study investigated on teachers' perception on availability of instructional materials and physical facilities in secondary schools of Arusha district, Tanzania. It utilized descriptive case study design and data was collected through questionnaire, interview schedules and documents. Simple random and purposive samplings were used to select a sample of 318 out of about 1049 selected school stakeholder in Arusha District. To establish validity, the instruments were given to experts for scrutiny who went through them against research questions and gave necessary recommendations for improvement before data was collected. A pilot study was conducted to schools which are not part of the sample and calculated using the SPSS. Reliability test yielded 0.727 Cronbach's Alpha for instructional materials and 0.778 for physical facilities which means the questionnaire was highly reliable.

The study concludes that there is inadequate number of textbooks, reference books, maps and globes in schools under investigation due to increase of students in Community Schools. Further, schools have inadequate physical facilities such as classrooms, desks, chairs and the available classrooms are poorly constructed with inadequate spacing. Researchers recommend that Curriculum developers at Tanzania Institute of Education together with policy makers should come up with a policy guideline that will enhance provision of instructional materials and physical facilities.

Korir and Kipkemboi (2014) investigated the Impact of School Environment and Peer Influences on Students' Academic Performance in Vihiga County, Kenya. The study examined the impact of school environment and peer influence on the students' academic performance. The study assessed school environment factors and peer influences in terms of the level of psychological impact they have on learners. The study was based on Albert Bandura's Social Learning Theory, which considers learning as an interaction between environment, behaviour, and one's psychological processes. The study used a correlation research design where school environment and peer influence constituted the independent variables whereas students' academic performance was the dependent variable. Twentyone public secondary schools in Sabatia District of Vihiga County were used in the study Based on these reviews, the researcher concludes that conducive learning environment is very essential for effective teaching and learning and recommendations were made among which includes, that government and other education stakeholders should make concerted efforts to build more classrooms in secondary schools that would help to reduce problem of overcrowding and create enabling teaching and learning environment; that adequate furniture should be provided and students should be oriented on how to maintain these facilities because most times students destroy these facilities by themselves. The quality of school facilities in Africa has received little attention from the relevant government authorities. Focus has been on getting as many children to school as possible regardless of the environments in which they learn. Many African countries are argued to celebrate the proportion of their populations in school over and above the quality of the education provided in these institutions.

Likoko, Mutsotso and Nasongo (2013) investigated the Adequacy of Instructional Materials and Physical Facilities on Quality of Teacher Preparation in Emerging Private Primary Teacher Training Colleges in Bungoma County, Kenya. The research was carried out in eight private teacher training colleges in Western Province in Kenya. The study sample was selected through simple random and purposive sampling techniques. The sample comprised of eight college principals, 43 tutors and 416 second year teacher trainees.

Pilot testing of the research instruments to establish how the sampled population would respond to the question items contained in the research instrument was very useful. Data was collected through questionnaires and observation checklists. The SPSS computer package was utilized in the analysis of descriptive statistics such as frequencies and percentages. The research findings were presented the results in form of frequency tables and pie-charts. The research established that the rapid emergence of private primary teacher training colleges had a negative impact on quality of teacher preparation. These institutions were faced with challenges such as; lack of adequate facilities like libraries and inadequate instructional materials. These factors continue to have negative effect on the quality of graduates produced. 
Aloyo (2015) investigated the relationship between physical environment and academic achievement in public secondary schools in Nairobi City County, Kenya. Does the settings where learning occurs matter? Research in North America and Western Europe shows that learning outcomes are hampered in physical environments where extreme climatic conditions are experienced. The settings and climatic conditions differ significantly in Sub-Saharan Africa as they are not as extreme. In fact leading researchers in Kenya offer mixed signals on the role of the school environment on achievement. This study sought to contribute to factors that explain learning achievement from the perspective of an architect planner rather than the predominant descriptive educationist viewpoint.

The objectives of the study were to examine the quality of the physical school environment, establish academic achievement among form four students and explore the relationship between the school physical environment and student achievement. The study adopted the case study research design. Public secondary schools were stratified into boys, girls and mixed categories. These were further stratified along eight geopolitical divisions in Nairobi County. Schools were proportionally allocated to the divisions. Systematic and simple random sampling techniques were employed to select the 36 schools investigated by the study. A revised Commonwealth Association of Physical Environment questionnaire, an interview schedule and an observation schedule revealed that the overall average quality of mixed schools' index of 126 was lower than that of boys' and girls' schools.

The indices for boys' and girls' schools were both equal to 134. In the Kenya Certificate of Secondary Education results of 2011, girls recorded the best performance with a mean grade score of 51.9 , followed by boys' and mixed schools with scores of 46.2 and 31.2 respectively. The extent to which the environment influenced the test scores, Pearson's $r$, revealed a positive correlation between the school environment and student achievement; $r=0.370, n=35, p=0.029$. Analysis of variance tests indicated that the impact of the internal environment and facilities on student achievement differed among boys', girls' and mixed schools; $F(2,7)=4.178, \mathrm{p}=0.042$.

The correlation and multiple regressions computed identified the key predictor variables of achievement as size in acreage of the school, availability of a title deed, aesthetics, security, school grounds, type of lighting, paintwork to interior walls, graffiti occurrence, classroom furniture condition and noise from the neighborhood. The study concluded that school physical environment contributes to student achievement. The task of improving school facilities from the foregoing results was noted. Focus is recommended on putting in place measures to upgrade old facilities, improve school grounds and control development around educational facilities.

In Marakwet east Sub County, the dismal status of physical infrastructures in public secondary schools has posed serious effect on students' academic achievements. Majority of the existing public secondary school buildings in the County lack adequate maintenance attention, thus being in deplorable conditions. In extreme situations students are highlighted in the media studying under trees and muddy classrooms. Yet the same students are expected to compete with their counterparts in well-developed physical environment with all the resources required for learning. These poor states of the physical infrastructures clearly highlights on the educational inequalities that exist in the Kenya education system which put the affected students at a risk of not achieving their academic achievements not because they cannot, but because they are treated unequally.

Within Marakwet east Sub County most of the secondary schools have inadequate infrastructure facilities and the ones present are in deteriorating conditions due to out of date designs and lack of maintenance. Secondary schools are experiencing many challenges relating to access and equity, including overstretched facilities, overcrowding, lack of appropriate sanitation and poor learning environments. With this state deficiency of infrastructure the quality of teaching and learning is affected and creates health and safety concern to staff and students (Asiago, 2018). With this state deficiency of infrastructure the quality of teaching and learning is affected and creates health and safety concern to staff and students.

\subsection{Gender Difference and its Effects on Academic Achievement}

Issues of gender and students' academic achievement have remained a controversial one for a long time world over. In the USA researchers have argued that males perform better than females in academics, while others have argued that the reverse is the case. For example, Lovejoy (2012) has explained that the influence of gender and differences in academic achievement is a complex task, 
thus many studies appear to be contradictory. He said a tremendous work has been done in an attempt to find out potential causes of differences between girls' and boys' academic performances in Social Sciences and this has clearly demonstrated that male students are superior to their female counterparts in qualitative courses. Ayayo (2007), in an investigation spanning twelve industrialized countries argued that the ability of both male and female students in their general academic achievements revealed that males were superior over females. This superiority was not confining to USA alone. This confirmed that the level of instruction held constant males achieved higher levels than females. She attributed this to difference in achievement to the school environment and programmes, and opined that prior to attending school, general intelligence of girls was higher than that of boys but the position gradually reversed with the findings. In most societies, gender has roles based on the women, preventing their participation in, and benefiting from development efforts (UNESCO, 2000). This has created bigger psychological alienation or depression in the minds of female students (Joel \&Aride, 2006). This has resulted in boys dominating Social Studies, Chemistry, Physics, and Mathematics and Environmental studies classes while the girls go into reading languages and Arts. United Nations (UN) has adopted various resolutions to ensure equal opportunities for all genders in education and empowerment. For instance, in 1982 UNESCO conference in Harare, African countries were called to set up structures in and at the National level to develop, absorb and use Science and Technology to distribute development tools among the various genders.

In United Kingdom, Younger and Warrington (2015) conducted an analysis of gender difference in academic performance. The study found out that although girls improved their performance in science and mathematics by Stage 4 in the UK, there was no comparable improvement of boys' performance in language arts subjects. The study highlighted that girls started to show signs of reducing the gaps in mathematics in later years, while the same was not true for boys in reading. The study highlighted the underachievement of boys in literacy begins early in the development years, leads to many boys entering secondary school with insufficient literacy skills for the demands of the curriculum in United Kingdom. The study was however conducted in United Kingdom a more developed country in terms of education as compared to Kenya. The reviewed study was delimited to girls and boys achievement in science and mathematics and literacy while the current study focused on difference academic achievement in all the subjects in Kenya. The study in Kenya focused on the overall performance of girls and boys without specific focused on the subjects.

The supposed crisis for boys, related to the training characteristics of expatriate teachers from Egypt, Jordan and Syria, has only been discussed in the UAE and not in other GCC countries; however, the UAE shares similar economic, social and political characteristics with the other GCC countries (Wiseman \& Anderson, 2012) including the hiring of expatriate teachers in secondary science and other high-need areas in education. This study investigates whether or not gender differences in 8th grade students ${ }^{\text {ee }}$ science achievement are associated with differences in teachers ${ }^{\text {ee }}$ training in the GCC countries using data from the 2007 Trends in Mathematics and Science Study (TIMSS). Significant differences were found in male and female 8th grade teacherse training characteristics across the countries of interest, but these differences were found to have no significant association with boys ${ }^{\text {ec }}$ and girlsee science achievement. The reviewed study was however conducted in GCC countries while the current study will be conducted in Kenya. The reviewed study focused on the effect of teacher training on gender difference in academic performance specifically science and mathematics subjects while the current study will focus on the effect of learning environment on gender differences in academic performance.

In Ethiopia, Mersha, Bishaw and Tegegne (2013) conducted a study on Factors Affecting Female Students' Academic Achievement at Bahir Dar University. The main purpose of this study was to investigate the on-campus and off-campus factorsresponsible for female students' low academic performance and consequently high attrition.Based on review of the related literature, basic research questions were formulated. For datagathering, both quantitative and qualitative research methods were employed. The quantitativedata were obtained through questionnaire. A pilot study was conducted to validate the instrument using 30 second year university students and was followed by the main study. The final versionof the questionnaire was administered for 600 undergraduate students at Bahir Dar University. The qualitative instrument constituted of document analysis, student records, and interview.The SPSS 13.0 was used for data analysis. Statistical techniques such as Percentage, CrossTabulation, Pearson Product Moment Correlation, t-test and Regression Analysis 
have been usedfor data analysis. Though the rate of attrition decreases, the number of female students' attritionhas increased. The problems female students encountered constitute personal, university relatedfactors, academic factors and economic factors. Previous academic background (high school)is one of the major factors for their low academic performance. The off-campus factors thataffect female students' academic performance include family background, Disco and traditionalMusic Houses and economic problems. In conclusion, the majority of problems female studentsencounter and those factors that affect female students' academic performance are personal andthe other problems are caused by the university environment.

Akpochafo (2010) reported that there is gender bias in Nigeria like in many African societies, a situation in which cultural beliefs and structural arrangement favour men over women as witnessed in many elective positions contestable by man and woman. Electorates see women as always not fit to rule or govern since men are involved. The idea that women should be under and submissive to men have created a negative influence in the life of women. In support of this, Anele (2008, p.73) explains that the socio-cultural practices of the African societies have placed men on positions that gives them domineering influence over women. Intrinsically, there is practically no significant difference in the intelligence between male and female that can be traceable to gender difference. The fact that men are even superior sex does not mean that they are artistically better than women (Okoye' 1987). Okeke (2007) equally observed that the school curriculum in Nigeria is not gender fair since its contents reflect mainly the concerns of males; sciences careers portray masculine images in the curriculum as well as females suffering from teacher overtly and covertly, knowingly and unknowingly.

It is obvious from the related literature reviewed that the role of gender in the academic achievement of students is a controversial issue. This is because some research findings revealed that gender plays active roles in students' academic achievement. Others reveal otherwise. This therefore leads to investigation of effects of gender on secondary students' academic achievement.

\subsection{Findings}

\section{$\mathrm{H}_{\mathrm{o} 1}$ : There is no Statistically Significant Difference between Mean Learning Environment Scores and Students Academic Achievement}

The following null hypothesis $\mathrm{H}_{\mathrm{o} 1}$ : there is no statistically significant difference between mean learning environment scores and students' academic achievement was tested at 0.05 level of significance. Table 1 displays the summary of means.

Table1. Descriptive Statistics for $H_{1}$

\begin{tabular}{|l|l|l|l|}
\hline & N & Mean & Std. Deviation \\
\hline egative & 4 & 3.4225 & .18839 \\
\hline Moderate & 4 & 4.1275 & .28710 \\
\hline Positive & 2 & 5.0850 & .07778 \\
\hline Total & 10 & 4.0370 & .67492 \\
\hline
\end{tabular}

The students' academic achievement was looked at in view of the learning environment in schools that was rated to be very negative, negative, moderate, positive and very positive. The dependent variable which was students' academic achievement had a mean of $3.42, \mathrm{SD}=.19$ in negative environment, 4.13, $\mathrm{SD}=3.68$ in moderate environment and 5.09, $\mathrm{SD}=5.09$ in positive environment.

Table2. ANOVA Summary Table for Hypothesis One

\begin{tabular}{|l|l|l|l|l|l|}
\hline ANOVA \\
\hline Mean & Sum of Squares & df & Mean Square & F & Sig. \\
\hline & 3.740 & 2 & 1.870 & 36.379 & .000 \\
\hline Between Groups & 360 & 7 & .051 & & \\
\hline Within Groups & 4.100 & 9 & & & \\
\hline Total & & & & \\
\hline
\end{tabular}

A one-way between groups analysis of variance $F(2,7)=36.379, p<.05$ indicated that there was statistically significant difference between mean learning environment scores and students' academic achievement. Therefore we reject the null hypothesis and accept the alternative hypothesis that there was statistically significant difference between mean learning environment scores and students' academic achievement. 
Findings have indicated that the ANOVA was significant, allowing to accepting the alternative hypothesis, and indicating that there is a statistically significant relationship between learning environment and students' academic achievement. This is consistent with studies done by Koroye (2016) who investigated the extent that physical school environment influences students' academic performance in secondary schools. The study revealed that aesthetic beauty of a school and infrastructural facilities influence academic achievements. The study also found school equipment and instructional materials to have greater influence on student's academic achievements. This study recommended for provision of enough physical facilities in all secondary schools in Baylsa State by Nigerian government to enable students to engage in meaningful learning.

Similar findings are also elicited by Adewuyi (2012) who argued that conducive learning environment can have effect on both the attitudes and achievement of students. He further added that a positive learning environment is found to be a very important factor of school effectiveness. Adamu (2015) in a study conducted to investigate the Influence of Learning Environment on Students' Academic Achievement in Mathematics: A Case Study of Some Selected Secondary Schools in Yobe State - Nigeria found out that, there is significance difference between the mean performance of students taught in an ideal learning environment and that of students taught in a dull learning environment. Lastly, a study by Byers, Mahat, Liu, Knock and Imms (2018) conducted a systematic review of the effects of learning environments on student learning outcomes. The systematic review identified evidence that different learning environments (blended, innovative learning environment (ILE), open-plan and traditional) have an impact on student learning outcomes. There are significant methodological questions around the availability and viability of empirical evidence.

\section{$\mathrm{H}_{\mathbf{0} 2}$ : There is no Statistically Significant Difference between Principals Gender and Students Academic Achievement}

The following null hypothesis $\mathrm{H}_{\mathrm{o} 2}$ : there is no statistically significant difference between Principals' gender and students' academic achievement was tested at 0.05 level of significance using independent sample $\mathrm{t}-$ test. Table 3 presents the group statistics

Table3. Group Statistics for $\mathrm{H}_{02}$

\begin{tabular}{|c|c|c|c|c|c|}
\hline \multicolumn{6}{|c|}{ Group Statistics } \\
\hline & Principal & $\mathrm{N}$ & Mean & Std. Deviation & Std. Error Mean \\
\hline \multirow[t]{2}{*}{ Mean } & Male & 5 & 4.3160 & .80426 & .35967 \\
\hline & Female & 5 & 3.7580 & .42833 & .19156 \\
\hline
\end{tabular}

An independent sample $\mathrm{t}$ - test was conducted to compare the students' academic achievement and the Principal gender in Table 3. The Male Principals had a mean of 4.32 SD $=0.804$ ) while female Principal had a mean of $3.76, \mathrm{SD}=0.428$ ). The 5 male Principals demonstrated a higher student's achievement level. Table4 presents the results of the independent samples test group for null hypothesis two.

Table4. Independent Samples Test Group Statistics for $H_{o 2}$

\begin{tabular}{|c|c|c|c|c|c|c|c|c|}
\hline \\
\hline & $\begin{array}{l}\text { Levene } \\
\text { of Var: }\end{array}$ & \multicolumn{5}{|c|}{ Thaependent Sampres rest } & & \\
\hline & $\mathrm{F}$ & Sig. & I & df & $\begin{array}{l}\text { Sig. } \\
\text { tailed) }\end{array}$ & $\begin{array}{l}\text { (2-Mean } \\
\text { Difference }\end{array}$ & $\begin{array}{l}\text { Std. } \\
\text { Difference }\end{array}$ & Error \\
\hline \begin{tabular}{|l|l|l|l} 
mean & $\begin{array}{l}\text { Equal } \\
\text { assumed }\end{array}$ & variances \\
\end{tabular} & 2.969 & 123 & 1.369 & & .208 & .55800 & .40750 & \\
\hline $\begin{array}{l}\text { Equal variances not } \\
\text { assumed }\end{array}$ & & & 1.369 & 6.100 & .219 & .55800 & 40750 & \\
\hline
\end{tabular}

An independent sample $\mathrm{t}$ - test in Table 4 indicated that there was no significant difference in male and female Principals and students' academic achievement, $\mathrm{t}(8)=1.37, \mathrm{p}>.05$, two tailed despite male principals $($ Mean $=4.32, \mathrm{SD}=0.804)$ being higher than female principals $(\mathrm{M}=3.76, \mathrm{SD}=$ $0.428)$.

\section{$\mathrm{H}_{03}$ : There is no Statistically Significant Difference between Learning Environment, Principals Gender and Students Academic Achievement}


Relationship Between Learning Environments, Principal's Gender and Students' Academic Achievement in Public Secondary Schools in Marakwet East Sub County, Kenya

The following null hypothesis $\mathrm{H}_{03}$ : There is no statistically significant difference between learning environment, Principals' gender and students' academic achievement was tested at 0.05 level of significance using two way ANOVA. Results are presented in Table 5 presents the results

Table5. Two Way ANOVA Summary Table for Null Hypothesis Three

\begin{tabular}{|l|l|l|l|l|l|}
\hline Source & $\begin{array}{l}\text { Type III Sum of } \\
\text { Squares }\end{array}$ & df & Mean Square & F & Sig. \\
\hline Corrected Model & $3.866^{\mathrm{a}}$ & 4 & .967 & 20.690 & .003 \\
\hline Intercept & 158.554 & 1 & 158.554 & 3394.196 & .000 \\
\hline principal & .120 & 1 & .120 & 2.561 & .170 \\
\hline learning gender & 3.087 & 2 & 1.544 & 33.047 & .001 \\
\hline $\begin{array}{l}\text { Principal } \\
\text { learning environment }\end{array}$ & .017 & 1 & .017 & .361 & .574 \\
\hline Error & .234 & 5 & .047 & & \\
\hline Total & 167.073 & 10 & & & \\
\hline Corrected Total & 4.100 & & & \\
\hline a. R Squared = .943 (Adjusted R Squared = .897) & & & \\
\hline
\end{tabular}

A two way ANOVA $\mathrm{F}(1)=0.361, \mathrm{p}>.05$ indicated that there was no statistical significant interaction between Principals gender and mean learning environment scores and students' academic achievement. Therefore we accept the null accept and reject the alternative hypothesis which had indicated earlier that there was a statistical significant interaction between Principals gender and mean learning environment scores and students' academic achievement.

\section{SUMMARY}

Finding showed that, boys' schools had a positive learning environment which was statistically significant as compared to girls and mixed schools.

An independent sample $t$ test was conducted to establish the relationship between Principals gender and students' academic achievements. An independent sample t - test was conducted to compare the students' academic achievement and the Principal gender. Group statistics indicated that male Principals had a mean of $4.32 \mathrm{SD}=0.804$ while female Principal had a mean of $3.76, \mathrm{SD}=0.428$ ). An independent sample $\mathrm{t}$ - test conducted showed that there was no significant effect of the Principals gender in students' academic achievement, $\mathrm{t}(8)=1.37, \mathrm{p}>.05$, two tailed despite male principals (Mean $=4.32, \mathrm{SD}=0.804)$ being higher than female principals $(\mathrm{M}=3.76, \mathrm{SD}=0.428)$.

A two way ANOVA $\mathrm{F}(1)=0.361, \mathrm{p}>.05$ indicated that there was no statistical significant interaction between Principals gender and mean learning environment scores and students' academic achievement. Therefore we accept the null accept and reject the alternative hypothesis which had indicated earlier that there was a statistical significant interaction between Principals gender and mean learning environment scores and students' academic achievement.

\section{CONClusion}

There was overwhelming evidence of a significant relationship between the learning environment and academic achievement of learners in public secondary schools in Marakwet East. Notably, the learning environment is detrimental to the attainment of higher achievements by learners. There are immense gaps in the teaching and learning resources. For instance professional development was noted to be low as indicated by a small number of teachers who were not involved in career progression. Specifically, majority of the mixed schools which also falls in the sub county category of schools had negative teaching and learning environment in most of the aspects under study such as opportunities to learn, provision of stimulating environment, operating on high expectation, and clear and consistent focus to learning. The study thus concluded that this impacted on the students' academic achievement in the mixed schools. Nevertheless, the teachers utilized a variety of pedagogic ideas bearing in mind the national curriculum guidelines.

There were immense gaps in the physical environment in the schools under study. For instance, the workload was not manageable and the class size was big. This occasioned congested classrooms with limited work space. This scenario was more pronounced in mixed schools than in the boys and girls schools. This had adverse impact on the academic achievement of students in the mixed schools as compared to the other schools. 
There was a relationship between type of school (students' gender) and academic achievement. Notably, boys' schools and girls' schools were performing better than the mixed schools. Lower performance of girls' schools and mixed schools as compared to boys is attributed to cultural issues such as early pregnancies, early marriages and house chores that are associated to girls in day's schools. The implication, therefore, is those female learners are at a more considerable disadvantage due to cultural issues and the limited provision of equal opportunities in the learning environment.

Despite schools headed by male Principals' performing better than schools headed by female Principals statistical tests indicated that the variances in the means were not significant. This implies that probably other factors may be influencing the performance such as physical resources available in the schools.

\section{RECOMMENDATIONS}

Based on the study finding, undoubtedly, the learning environment is crucial determinant of the academic achievement of learners. Consequently, there is need for concerted efforts by the public secondary schools to ensure they develop an effective teaching and learning, physical and social environment. Since the schools in Marakwet East lack sufficient classrooms more so mixed schools and by extension the sub county schools, there is need for concerted efforts by the school management in seeking more funding to cater for the construction of more classrooms, laboratories and libraries. The schools could consider writing a proposal to seek funding from donors to improve on the school infrastructure. To improve on the teaching and learning environment the government through the MOE needs to give priority to schools in hardship areas such as Marakwet East. Assistance should be in form of more recruitment slots to be given. With adequate teachers the study feels that, the teaching and learning environment can be enhanced. Such as move will make teaching and learning interactive.

Information Communication and Technology which was lacking in most of these schools need to be availed to make learning more interactive. Teachers need to be taken for workshops and encouraged to progress career wise. This will compliment there methodological capabilities.

So as to improve the performance of both male and female students, all genders need to be provided with equal opportunities in the learning environment. There is need to avail more teaching and learning resources particularly in the sciences. Through the CDF mixed schools should be provided with funds for the construction of laboratories.

\section{REFERENCES}

[1] Adewuyi, (2012). International Journal of Sustainable Built Environment. 1(2), 167-176, 2012. Nigeria

[2] Adeyemi, T.O.(2008). The influence of class-size on the Quality of Output in Secondary Schools in Ekiti State, Nigeria. Pakistan Journal of Social Sciences. 5(2):202-208.

[3] Ajayo, W. (2001). Curdbury is Determined to Move Education Forward. Vanguard, december 27 2001,P.16

[4] Akomolefe, C.O., \& Adesua, V.O. (2016). The impact of physical facilities on students' level of motivation and academic performance in senior secondary schools in South West Nigeria. Journal of Education and Practice, 7(4), 38-42.4

[5] Akubue, A U (2006) “Classroom Organization and Management: A 5-point Strategy”. Ibadan: Wisdom Publishers Ltd.

[6] Al-Enezi (2002).Relationship Between School Buildings and Academic Achievement in $12^{\text {th }}$ grade students in kuwait.

[7] Bogonko, S. N. (1992). Reflections on Education in East Africa. Nairobi: Oxford University Press.

[8] Carothers, B. J., \& Reis, H. T. (2013). Men and women are from Earth: Examining the latent structure of gender. Journal of personality and social psychology, 104(2), 385.

[9] Cohen, J. (2015). Transforming school climate: Educational and psychoanalytic perspectives: Introduction. Schools, 6(1), 99-103.

[10] Kashu, J.N., (2014).Survey on gender and academic performance in secondary schools in Kenya. Doctorate Dissertation . University of Nairobi, Kenya.

[11] Kiptum, J. K. (2018). Influence of School Physical Environment on Teachers'satisfaction In Selected Public Primary Schools In Elgeyo Marakwet County, Kenya (Doctoral dissertation, KENYATTA UNIVERSITY). 
[12] Kirui R K (2005). Provision of Career Information Resources to Secondary School Children in Eldoret Municipality in Kenya.Moi University, Eldoret, Kenya,2005; 4-5

[13] Koroye, T.(2016). The influence of school physical environment on secondary school students' academic performance in Bayelsa state, Nigeria. Asian Journal of Educational Research. Department of Curriculum Studies Isaac Jasper Boro College of Education Publishers.

[14] Lulley, S. (2018). Social Conflicts Affecting Teaching and Learning in Public Primary Schools of Elgeyo Marakwet County, Kenya. African Journal of Education, Science and Technology, 4(3), 140-149.

[15] Namusisi, N. F. M. (2015). Capital Markets and Financial Resource Mobilization in Developing Countries. Deepublish.

[16] Obanya, P (2003) “Thinking and Taling Education”. Ibadan: Evans Brothers Nigeria Limited.

[17] Raturi, S., \& Kedrayate, A. (2015). Impact of elearning on primary school children and teachers: A study of the one laptop per child pilot project in Fiji. International Journal of Instructional Technology and Distance Learning, 12(8), 3-23.

[18] Rohana, K (2017).The Quality of Learning Environment and Academic Performance from a Students Perception. "International journal of business and management", 4(4), 171-173.

[19] Ruszala, J. A. (2008). The condition of the high school facilities in the Commonwealth of Virginia's metropolitan school divisions and the relationship to teacher satisfaction (Doctoral dissertation, The George Washington University).

[20] Tshui, C Y and Cai, D (2011) Developing a System for maintenance of teaching college Laboratory Equipment. "Journal of Vocational and Adult Education", 3(1), 11-22

[21] Yusuf, M.A. and Adigun, J.T. (2010). The Influence of School Sex, Location and type on students' Academic performance. International Journal of Education Science Journal of education science, 2(2): 81-85.www.american-jiras.com

[22] Yusuf, A. (2004) "Effect of Cooperative Instructional Strategy on Students Performance in Social Studies". Retrieved from http://www.socialstudies.org/wasington.

\section{AUTHOR'S BIOGRAPHY}

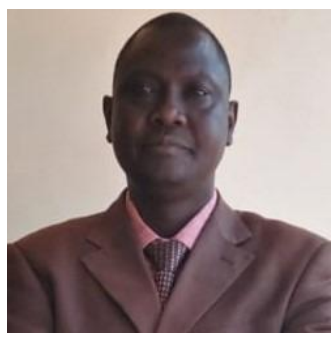

Mr Charles Kisigot, was born on 8th August 1970 in Marinda farm,Kitale. $\mathrm{He}$ has a Masters Degree in Education from Moi University Eldoret, a Bachelors degree of Kenyatta University, Diploma (Special Needs Education) from Kenya Institute of Special Education,a Post Diploma Certificate in Educational Audiology,and Primary Teacher Education Certificate(P1). He has taught headed several primary and secondary schools, in a teacher training college and has worked as a Graduate Assistant at CUEA- Gaba Campus. Currently he is an Education Officer at Uasin-Gishu County, Curricula Support Officer in Charge of SNE programmes.

Citation: Charles K. Kisigot, et.al. "Relationship Between Learning Environments, Principal's Gender and Students' Academic Achievement in Public Secondary Schools in Marakwet East Sub County, Kenya" International Journal of Humanities Social Sciences and Education (IJHSSE), vol 8, no. 3, 2021, pp. 26-38. doi: https://doi.org/10.20431/2349-0381.0803003.

Copyright: () 2021 Authors. This is an open-access article distributed under the terms of the Creative Commons Attribution License, which permits unrestricted use, distribution, and reproduction in any medium, provided the original author and source are credited. 